\title{
David Stow: Christian educator in nineteenth century Scotland
}

\author{
Stephen J. McKinney ${ }^{1}$ (D)
}

Published online: 2 July 2020

(c) The Author(s) 2020

\begin{abstract}
The educational work of David Stow evolved in three phases. He established a Sabbath school and helped to introduce both infant schooling and teacher training in Glasgow, Scotland in the nineteenth century. He helped to establish the Glasgow Normal Seminary and later he joined the Free Church of Scotland Normal Seminary. Stow was a committed Presbyterian Christian, and this motivated him and was at the centre of all of the three phases of his educational work. He was dedicated to the school education of the poor, similar to other educators of his time. He understood this mission to the poor as a means to rescue them from the corrupting influences in their urban settings. The corrupting influences would be replaced, however, by social control and the promotion of Christianity. This article presents an examination of the close links between his strongly held Christian beliefs, Christian worldview and his vision of schooling and teacher preparation.
\end{abstract}

Keywords David Stow · Glasgow Normal Seminary · Religious education · Bible

\section{Introduction}

The name David Stow (1793-1864) is known in the city of Glasgow because the Stow College that was opened in 1934 was named after him. This is located not far from the centre of the city and is now named the Stow Building, School of Fine Art Studios and Workshops of the Glasgow School of Art. However, there is another building not far from the Stow building that is directly associated with Stow. This is the building that used to be the original Glasgow Normal Seminary (later Church of Scotland Normal Seminary) and, while tragically is no longer in use, remains a physical sign of the work and legacy of David Stow.

His achievements as an educator of the young and his role in the evolution of formal teacher training are, arguably, not as well-known as they should be. This is despite some key works by Cruikshank (1966), Wood (1987) and White (2010). This represents a significant gap in contemporary knowledge and understanding of his role in the history of education in the United Kingdom. The lack of contemporary recognition is disappointing as

Stephen J. McKinney

Stephen.mckinney@glasgow.ac.uk

1 School of Education, University of Glasgow, Glasgow, UK 
Stow helped to introduce infant education to Glasgow and contributed to the establishment and development of the 'Normal Seminaries'. Further, he deserves greater attention for his vision of a Christian education. He had a clear vision that the aim of education was to educate the whole person and that entailed education of the intellectual and physical but very clearly within a religious and moral framework. Christian education and moral formation were integrated into all aspects of the school day. He was dedicated to the school education of the poor and he shared this dedication with other educators of his time, such as Bell, Lancaster and Wilderspin. He understood this mission to the poor child as a means to rescue them from the corrupting influences and immorality in streets of their urban settings. The corrupting influences would be replaced, however, by social control and the promotion of Christianity.

This article focusses on the educational work of David Stow, his Christian principles and the influence of these principles on his approach to education and to his educational methods. The article will also examine the social and religious control inherent in his approach to educational training, whether the training of children or the training of teachers. The article begins by positioning David Stow within the context of some of the innovations in education in the eighteenth and nineteenth centuries. The article continues with his early life and work in Glasgow and the first phase of his educational work: his engagement with the Sabbath schools. The article then looks at the second phase of his educational work: his involvement in establishing the Glasgow Infant Society and Infant schools in Glasgow. The next section examines the third phase of his educational work: his commitment to teacher training and the inception of the Glasgow Normal Seminary. Further sections explain the development of the Glasgow Normal Seminary and the impact of the disruption of 1843 which led to David Stow's involvement with the Free Church of Scotland Seminary. The final sections provide an overview of the influence of the Training System and the Normal Seminary in different parts of the world and a concise analysis of the legacy of David Stow.

\section{David Stow within the context of innovation in education in the eighteenth and nineteenth centuries}

David Stow is positioned in the context of the advances in education and social reform in Britain in the late 18th and early nineteenth centuries because of his work in educating the poor and preparing teachers in Glasgow. He engaged with educational ideas within a particular historical socio-economic, educational context, but also, and crucially, within a particular religious context. He was an ardent Christian who had strongly held beliefs, like many of his contemporary innovators in early forms of schooling. A number of these innovators used schools to promote the Christian faith (Sedra 2011). Bell and Lancaster were both famous for the use of the monitorial system, sometimes known as the Bell-Lancaster method. The reverend Dr Andrew Bell established a school in Madras in 1798 for the illegitimate children of European soldiers (Tschurenev 2008). This was to save them from the 'corrupting' influence of their Indian mothers. He evolved a method of the more able pupils teaching or instructing the other pupils and he continued to use this method when he returned to England.

Joseph Lancaster introduced a monitorial teaching system in his Borough Road school in Southwark (founded in 1798) (Aldrich 2013). The method involved the teacher teaching a small group of the more able pupils who would act as monitors and pass on what they had learned to other groups of pupils. Lancaster developed a strong element of competition 
within his monitorial system. The monitors could be changed because some monitors were less successful and their place would be taken by another pupil who showed promise (Tschurenev 2008). There were prizes for those of 'superior merit' (Stewart and McCann 1967). The system was deemed to be efficient and, partly relying on small weekly fees paid by the families, was very economic. The 'cheap' system enabled day schools to proliferate (Murphy 1971). The monitorial system became the preferred system used in the mission institutes founded by the British and Foreign School Society (BFSS), a Society that Lancaster helped to form in 1808. Some of the chief historical criticisms of the monitorial system were that it was overly focussed on the memorisation of facts, it was based on a model of competition between the pupils and the role of the teacher could be reduced to that of a supervisor, supervising the work of the monitors (Hamilton 1989). There are also contemporary criticisms of the overall aim of the monitorial school, which was ostensibly to educate the poor and disadvantaged, but was also a process to create a 'docile subject' and a Christian who would understand his or her role in society (Murphy 1971; Newman 1998). This aim was often subverted by the children who did not correspond to the idealised image of childhood that this education presupposed and they refused to be moulded (Oswell 2013, p. 117).

The aim of the BFSS was a non-sectarian, or non-denominational, Christian religious education and while there was an emphasis on scripture and Christian doctrine, there was to be no proselytising and an avoidance of distinctive denominational tenets and catechisms (Murphy 1971). Nevertheless, the Secretary of the Society did acknowledge in 1838 that the teacher explanation of a passage of scripture might be coloured by their denominational position.

Infant schools had been established by Robert Owen (influenced by Johann Pestalozzi) in New Lanark, Scotland in 1816 and by Samuel Wilderspin in Spitalfields, London in 1820 (Davis and O'Hagan 2010; Donnachie 2014). They served a number of purposes in providing education for young children (many now released from child labour) and freeing up their parents and siblings to work rather than look after them during the day (Woodham-Smith 2012). While on business in London in 1820, Stow visited Samuel Wilderspin's Infant School in Spitalfields. This convinced Stow that education should begin as early as possible and that day schools were the most effective schools (Whitbread 1972). Stow was very influenced by Wilderspin's methods and adopted the idea of a gallery and the use of cards, pictures and real objects in religious instruction (McCann 1966). However, Stow considered Wilderspin's approach to religious and moral education to be insufficiently rigorous. Closer to home, Robert Owen had established an infant school in New Lanark, but this was based on a secular vision of school education (Rusk 1933). This clearly differed markedly from the approach of Stow, and Stow was critical of Owen's approach to infant education, strongly affirming the importance of moral and religious tuition and the truth of the gospel. (Glasgow Infant Society 1829; Markus 1993).

\section{Early life and phase 1: the Sabbath schools}

David Stow was born in Paisley, close to Glasgow, on the 17th May 1793. He was brought up in a sincere and devout Christian family. The family was highly diligent in their religious devotions and practices and scripture was at the heart of their faith (Fraser 1868). The frequent visits of Rev. Dr. Love provided the example of a pious clergyman. This contrasts with his time as a pupil at Paisley Grammar where he experienced a mechanical instruction 
with no explanations and the religious instruction was limited to reading the Bible. While Stow was highly motivated by his religious faith, it was clearly a faith that was fostered in the 'gentle piety and religious training' of his home upbringing (Cruikshank 1966, p. 205). He lived and worked in Glasgow and he became very anxious about the serious impact of poverty on the lives and moral character of the children in the densely populated city (Chambers 1838; O'Donoghue and Moore 2019). The population of the city was 94,939 in 1801 and by 1841 had risen dramatically to 308,275 (GB Historical/University of Portsmouth 2020). Stow devised his own classification for society in Glasgow: the wealthy, the rising, the sinking and the sunken in a ratio of 1:2:2:1. He subdivided the 'poor and working population' into the following three classes: 'the Sunken, the Sinking and the Uprising' (Stow 1859, p. 22).

Dr Thomas Chalmers (1780-1847) who was appointed Church of Scotland minister to the Tron Church in 1815 and then in 1819 to St. John's in Gallowgate was to be a major influence on Stow (Goodlad 2003; Fraser and Maver 1996). Chalmers was anxious that Glasgow did not have endowed parish schools that were a feature of many rural parts of Scotland and as a result many of the children were not educated (Murphy 1971). This was particularly marked in the poorer areas. He thought that Sabbath schools would help ameliorate this situation (Brown 1982). The Sabbath schools were voluntary schools that became popular in England in Scotland from the 1780s onwards and were established in Glasgow in 1786 (Murphy 1971). Chalmers established a local parish Sabbath school society in 1816 that was aimed exclusively at children of the Tron Parish. When Chalmers moved to St. John's parish in Glasgow, he established Sabbath schools and also day schools modelled on Scottish rural parish schools.

Stow became one of the elders of St. John's Church and was very impressed by Chalmers and his work in creating the Sabbath schools. Stow was also influenced by his father who had helped to establish a Sabbath school in Paisley (Fraser 1868). He opened a Sabbath School in the Saltmarket in Glasgow in 1816 and took time to meet the parents and understand the circumstances of the lives of the families. From the outset Stow was concerned with the teaching of scripture and the best methods of Bible study with children. Stow was opposed to passages of scripture being committed to memory as learning by rote would not have any effect on the moral character of the children (Stow 1834). He also advised that approaches to Bible study that were overly focussed on the narratives or history of scripture or on the 'high doctrines' should be avoided. He acknowledged that these approaches should be recognised but he argued that the principle was to draw 'from the pupils, the natural and practical lesson from each passage' (Stow 1859, p. 2).

The Sabbath school was successful but, nevertheless, Stow became very aware of the limitations of this form of schooling and the need for full time education for children (Betchaku 2007).

\section{Phase 2: the Glasgow Infant School Society and the Infant Schools}

Stow was instrumental in founding The Glasgow Infant School Society which was established in 1827 with the purpose of opening an infant school for children aged two to six (Cleland 1832; White 1996). The Society rented premises in the Drygate near Glasgow Cathedral and the school was opened on the 23rd of April 1828. The school was furbished with a gallery of tiered seats for one hundred children and there was a large playground outside (Cruikshank 1966). The school was conceived as a 'model school', that is a school 
that would provide an effective and practical example of infant schooling that could be imitated in other parts of the city and Scotland.

Stow and Thomas Chalmers did not ascribe to what was then understood as 'gratuitous education'. The funding for the schools was a 'mixed system' of part permanent endowment (from wealthy citizens) and modest fees from the pupils. The fees were set at two pence per week per child or three pence for two children from the same family. The fees were paid on Mondays (Cleland 1832). Chalmers and Stow thought that parents would attach more importance to schooling if they were required to contribute financially and if education was perceived to be part of the family expenditure. Further the income was very welcome to support the schools. Stow would later seek state funding to support the Glasgow Normal Seminary, but this too was a 'mixed system' where the Church, the Seminary and the state would share costs.

Stow had a concept of schooling that was rooted in educating the young and training their moral character. Stow's concept of moral education was deeply rooted in Protestant morality and illustrates the central importance of the principles of Christianity in the earliest formal processes of school education (and later, the training of teachers) in Scotland. Stow's ideas developed over time from his experiences in the schools and his methods were unusual in Scotland for the period. Stow understood the words training and teaching in a distinctive way. He associated teaching with instructing or lecturing, in other words, a didactic or transmissive mode of teaching and the child as the passive recipient of the knowledge. He understood training to be focussed on ensuring that the children are actively participating in their own learning, they practiced skills and acquired moral habits (White 1996). The appropriate training would support the children in resisting the darker influences surrounding them in the streets, wynds and closes in the city. The Third Report of the Glasgow Educational Society's Normal Seminary describes this as the 'evil companionship on the streets' (1837a, p. 6).

Stow was very committed to co-education in the pupil body and was opposed to teaching boys and girls separately (except for activities such as sewing). This was motivated by his concern for the moral training of the children. He thought that separate teaching and even being taught together created a risk to their character. The risk is removed when they are morally trained together (Glasgow Educational Society 1837b). He thought girls and boys had a positive influence on each other. The girls would morally elevate the boys and the boys would intellectually elevate the girls (Stow 1856, p. 120). Stow rejected physical punishment and strict rules: the rod was not used in the Model schools of the Glasgow Educational Society. In taking this stance, Stow differed from Chalmers who believed 'a good cuff at the right time would be more effective than words' (Wood 1987, pp. 19, 66).

Stow adopted the use of a gallery in the Drygate school and an assembly of all of the pupils at least twice a day, usually at the beginning and the end of the day. At the end of the day the assembly in the gallery was used to discuss the behaviour during the day so that appropriate moral training could be provided. There was praise and prayer at the beginning and the end of the day and Bible training in the morning and the 'secular' subjects throughout the day. Scripture was taught using narrative, picturing out in words, objects and questioning so that the children could remember the meaning of the Biblical passages. Stow did not limit the religious and moral instruction to scripture, but also used stories to help the children reflect upon their behaviour (Paterson et al. 2012). While the children were supposed to come to their own conclusions from the reading, they were carefully guided by the teacher.

The constant contact of the teachers with the pupils extended to playground activity. The playground was perceived by Stow to be 'the uncovered school' or the 'child's 
little world' where the child would unconsciously reveal herself (Cruikshank 1966, p. 208). The teacher could observe the different types of behaviour of the children in the playground while supervising the games. Stow encouraged the trainers to join in the games (Glasgow Educational Society's Normal Seminary 1837b). Stow argued that without a playground and the observations of the master there could be no moral training. The behaviour demonstrated in the playground (for example, selfishness or kindness) would be used for discussion in the gallery. Stow talked about the 'sympathy of numbers', using the peer group in a positive way in the gallery.

\section{Phase 3 in education: the training of teachers and the Glasgow Normal Seminary}

Stow became concerned about the quality of those who were teaching and turned his attention to the training of teachers. In 1834, he outlined the qualities required in an Infant School Master (Stow 1834, p. 90):

Of course, they must have a natural fondness for young children - they must be cheerful in disposition and condescending in manners - they must be possessed of general information and have a facility of narrating stories - above all, they must have sound moral and religious principles.

Stow recommended that a man should be the head of any juvenile or infant training school and his wife or sister should be his assistant. This was to strengthen the idea of the family system carried into the school.

Stow was involved in the creation of the Glasgow Educational Association which later became the Glasgow Educational Society. The Glasgow Educational Association advertised in the Scottish Guardian on 23rd of January 1835 for a 'Gentleman of liberal education' who would spend a year studying schools in England and the Normal Seminaries of Prussia and who would then be appointed in charge of Seminary in Glasgow for the Training of Schoolmasters (Wood 1987). The candidate would be expected to lead the school and lead by example in Christian beliefs and lifestyle and so would be of 'decided Christian character, and a member of the Established Church of Scotland'. The lack of response prompted a second advert in the Glasgow Herald on 11 September 1835 and Mr. McCrie was appointed as Rector in 1836.

Stow did not approve of the use of monitors as advocated by Lancaster and Bell who only taught facts and were a poor substitute for a school master (Stow 1839). Stow was anxious about children who were teaching other children not much older than themselves - an anxiety that would see him being equally critical of the pupilteacher system that developed later in Scotland (Hamilton 1989; McDermid 2012). Stow opted instead for an alternative: 'simultaneous instruction', a form of systematic simultaneous instruction that used ellipses to invoke simultaneous answers, with some individual answers to check inattention and for 'particular examination' (Stow 1856, p. 167; Rich 1933; Komatsu 2003). It was noted by Bache, an American visitor in 1836, that the first sounds of a missing word were frequently supplied (Bache 1839, p. 163). 


\subsection{The development of the Glasgow Normal Seminary}

In 1837 new premises were acquired in Dundas Vale to house the growing population of the Drygate school. These new premises, under the guidance of the Glasgow Educational Society, provided four model schools for different age groups and a Normal Seminary (or School) for teacher training. Stow was convinced that training for teachers was essential and the Normal Seminary was the ideal institution (Stow 1839).

Stow argued for public grants to support the establishment of training schools. He proposed that the grant should be equivalent to half of the twenty million pounds that was spent to compensate slave owners for the emancipation of the slaves in the West Indies in 1834 (Stow 1834, p. 61). This twenty million pounds was the equivalent of forty per cent of the national budget at that time (Ritchie 2018). In other publications he would amend this proposal to the full equivalent of the $£ 20$ million (Stow 1854, p. 110). The public grant money would be used to purchase land, erect buildings and defray the cost of schooling for the families. Stow understood that people might baulk at such a sum, but he argued that the sum would be repaid thrice over in 'superior industry, sobriety, and good order of the working classes' (Stow 1839, p. 10).

Stow combined the instruction in methods and the extension of the subject knowledge of the students (Jones 1924). This prepared teachers for all kinds of schools, both at home and abroad (Gordon 1856). Stow proposed two fundamental principles of new establishments for education: First, The mode of communication and discipline. Second, the platform and apparatus (Stow 1839). Both of these are essential to the education of the children. The premises included sixteen classrooms, a gallery, playgrounds, a library and a museum and a capacity for 1000 children and 100 students.

Stow (1839) believed that the trainer must be provided with the 'proper instruments of labour':

...the following may be considered as the principal. The scriptures being the only standard of God's moral law, are the foundations of the moral training department. The Play-ground, or the Uncovered School, of sufficient dimensions, is the platform for the development of the real dispositions and habits of the children, and for moral superintendence by the trainer; the Gallery, for intellectual sympathy of numbers, development and discipline; and the union of Gallery and Play-ground, for the practical exercise of moral training.

Stow argued that his model and the sympathy of numbers were the only ways to address the moral degradation (especially in cities and towns). Stow was emphatic that other forms of education would fail if there was no moral training:

Nothing short of Christian precept, doctrine, and motives, in Divine blessing, can accomplish this work. Education is abortive at present. Why? Because it is teaching the head, not training the "the child" - late, not early (Stow 1839, p. 20).

From Stow's perspective, the moral degradation could only be addressed by properly trained teachers, fully conversant in the scriptures, and a school day that offered a variety of opportunities for moral training in the classroom and in the playground.

The student body, like the pupil body, was co-educational and anybody who sought admission to the Normal Seminary to become a trainer would require a 'sufficient amount of elementary knowledge' and a certificate of character from the minister (Stow 1839, p. 26). The Presbytery alone could decide if the person was fit for the office by 
being of good moral character. There were only two schoolbooks that the presbytery could insist upon being introduced into the seminary: The Bible and the Westminster Assembly's Shorter Catechism. The student body was non-residential but, like the pupils, they had to be preserved from the 'contaminating influences of a large city'. They were lodged in boarding houses kept by persons of known moral and religious character who could be trusted to report any 'flagrant improprieties of conduct' unbecoming to the profession (Gibson 1841).

The report by John Gibson provides an invaluable snapshot of the working week of the students at the Glasgow Normal Seminary. In 1841, the working week for the students was 40 hours and they spent sixteen and a half hours of their time on study (receiving instruction on music, geography, natural history, physics, arithmetic and algebra, sacred history, drawing, elocution and gymnastics) and the rest of the time on training in teaching and in explanation of education (Gibson 1841). The time devoted to training was for 'skill in the art of teaching' and to receive communication on enlarged and enlightened views on education. There were four means of accomplishing this: observing the model schools; teaching lessons to the children in the gallery and in classes; the students would provide a Bible lesson to each other and time spent in public criticism. The students trained for six months. The initial duration of training of six months was later extended to eight or nine months and later to a year. Stow robustly defended the necessity of a lengthy training and considered it only a beginning to their practice of this model.

The six-month training period was divided into three periods that were progressively more concentrated on teaching the pupils. The students would observe for the first two months. In the next two months they would both observe and begin teaching and in the final two months they would be devoted to teaching. The tutors would 'model' lessons and there were criticism lessons. Every Wednesday afternoon, four students would each deliver a lesson to either the senior or junior children in the gallery for 15 minutes in succession. Each of these four lessons began with physical activity and ended with the singing of a verse or two of a psalm or a hymn led by the student. The Bible lesson that a student delivered to his fellow students was a carefully constructed exercise. The student who was teaching the lesson delivered the lesson to the other students in the gallery. He taught the lesson as he would have taught a class of children of a particular age group. The students were expected to ask the kinds of questions that would have been forthcoming from children of that age group.

The College struggled financially, and Stow managed to secure $£ 1000$ from the Committee of Council of Education in 1839 though the condition was that the seminary could be inspected. This would help to ensure the correct use of public expenditure (Murphy 1971). However, the inspectors would not be allowed to interfere with the religious training (Wood 1987). By the autumn of 1840 the government had awarded the Normal Seminary $£ 4500$. The inspection report of 1841 reveals that there were only 55 students. The College debt increased to $£ 10,677$ and the state offered aid of $£ 5000$ to offset the capital costs in 1843. The Church of Scotland was to raise the rest of the money. One of the conditions was that the management of the College was transferred to the Church of Scotland Assembly Education Committee, a process which was concluded in May 1845 (Stevenson 2012).

\subsection{The impact of the disruption of 1843}

Internal divisions within the Church of Scotland led to the emergence of a splinter Presbyterian Church, the Free Church of Scotland. This became known as the 'Disruption' and 
474 ministers and around half of the laity of the Church of Scotland joined the Free Church (Mallon 2020). The 'Disruption' was to have a serious effect on David Stow and the future of the Glasgow Normal Seminary. Thomas Chalmers was the leader of the newly formed Free Church and David Stow and the majority of the staff of Glasgow Normal Seminary joined the Free Church (Brown 2019). Once the Church of Scotland had assumed management of the Glasgow Normal Seminary in 1845, as agreed in the financial resolution, those who seceded to the Free Church were no longer allowed to be members of staff. The Glasgow Educational Society was willing to work with the Church of Scotland in teacher training, but this offer was rejected. David Stow left the College on the 8th of May and led the directors, students, pupils and the teachers (bar one) to Cowcaddens to support the Free Church of Scotland Normal Seminary (later the United Free Church Training College in the early twentieth century) in Glasgow (Hillis 1996, pp. 13-14). In consolidation of his new denominational status and in recognition of his achievements in education, Stow was invited to became a member of the Education Committee of the Free Church of Scotland less than a month later on the 2nd June 1845 in Edinburgh at session 18 of the General Assembly (Free Church of Scotland 1845, p. 82).

The new building for the Free Church of Scotland Seminary was completed in 1845 and, thanks to a government grant and the generosity of supporters of the Free Church in Glasgow, was debt free by 1848 (Free Church of Scotland 1848, p. 299). The disruption was to have an interesting effect on school education and teacher training in Scotland as a dual system of Presbyterian Normal Seminaries emerged in Glasgow, Edinburgh and eventually Aberdeen to support the dual system of Church of Scotland and Free Church of Scotland schools (Free Church of Scotland 1847, 1848, p. 300; Nicoll 1984). The Glasgow Normal Seminary in Dundas Vale became known as the Church of Scotland Normal School and the Normal School in Cowcaddens as the Free Church Normal School. The state grants were partly awarded to the Seminaries according to the number of students and this may help to account for the range of Christian denominations in the student body in the Free Church of Scotland Seminary. In 1872 it was noted that Lizzie Morgan, a Roman Catholic, had taken the entrance examination and was eligible for a scholarship, a scholarship that was awarded by the Committee of Management (Hillis 1996, p. 19).

David Stow was invited to be the honorary secretary of the Free Church Normal School in Glasgow and continued to oversee the work of the school and attended the majority of the meetings until 1861 three years before his death. As has been stated, Stow was highly critical of the pupil-teacher scheme which was introduced in Scotland in 1846. The students sat an examination for entry to the College and many successful applicants had been part of the pupil-teacher system. They had been recruited at thirteen for a five-year apprenticeship and entered the College in their late teens. The system would last until 1905. The pupil-teacher system did provide much needed assistance to teachers and helped some young people progress to becoming a certificated teacher but was ultimately exploitative as the young people had to work long hours and study at the same time (Wilson 1967; Wood 1987, p. 49).

\section{The influence of the training system and the Normal Seminary}

The influence of Stow can be traced to the creation of Normal Seminaries or Colleges that adopted his training system in places such as Antigua, Ceylon, Cheltenham, London and Westminster (Stow 1850). The Bengali Training Manual, for example, that was used in the 
mid 1800s was ultimately based on David Stow's training method (Sengupta 2011). There was also a demand for teachers who had been trained in the Glasgow Normal Seminary in Scotland and England, but also the West Indies, Australia and Canada.

\subsection{Influence on Scotland and England}

The Infant School movement, as envisaged by Stow, was quite short lived, it began to fail by 1839 but it did influence later developments. (Wood 1987). The role of the two seminaries in supplying teachers was more successful. A wide range of places in Scotland and England requested trainers from the seminary (Glasgow Educational Society's Normal Seminary 1837b). The Wesleyan Methodist Conference supported the training of teachers between 1839 and 1851 in Glasgow and were often the largest group in the seminary (Moody 1844; Free Church of Scotland 1848). The vast majority of the Wesleyan male and females assumed teaching roles in England. A small number ventured to different parts of the world, including the South Sea Islands and the West Indies. The flow of Wesleyan students was curtailed when the Wesleyan Normal Seminary was opened in Westminster in 1851 (Stow 1850). The first Rector was Mr. Sugden who had been a member of staff of the Free Church Normal School.

Sir James Kay (later Sir James Kay-Shuttleworth) considered the Glasgow Normal Seminary to be the first 'genuine training institution' in Britain (Connell 1950, p. 7). Dr Kay was impressed by the Normal Seminary in Glasgow and argued that every district orphan school should be constituted in the same way. The school was like a house and combined with the playground (the uncovered school) was the necessary corrective influence to the corrupting influence of the streets where the children lived (Kay 1838, p. 158; Thompson 2018).

\subsection{Influence in the wider world}

In 1835, around 20 school masters were brought to the West Indies by the Reverend Archdeacon Trew, the superintendent of the Educational Christian mission (Circular of Information 1872). All of the school masters had trained at the Normal Seminary in Glasgow. The Third Annual Report of the Glasgow Educational Society's Normal Seminary 1836 adds that four teachers trained in the seminary had gone to Jamaica in 1836 , one to be a catechist and three to be infant teachers. While acknowledging the demand for those trained by the Normal Seminary, it has to be recognised that the role of these missionaries, teachers and catechists was to educate and catechise, but also to socialise and civilise.

Stow's ideas influenced pedagogy in parts of Australia (Campbell 2014). The model schools set up in Australia were influenced by the model schools established by David Stow and Kay-Shuttleworth (Theobald 1996). The Normal Schools in Glasgow sent a steady number of teachers to Australia. The fourth report of the Glasgow Educational Society, for example, noted that seventeen teachers had been trained for Australia and had sailed in July and August 1837 under the direction of Rev. Dr. Lang (Glasgow Educational Society 1837a).

There are a number of inter-related examples of the influence of the Glasgow Normal School in Cape Breton, Canada. Hugh Munro who had qualified at the Glasgow Normal School helped to establish a school in Boularderie in Cape Breton in 1837 with the support of Mrs Mackay and the Mission of the Edinburgh Ladies' Association of Cape Breton (Stanley-Blackwell 1983). After two years he then moved to Middle River. After a further 
two years, he left for the Royal Acadian School in Halifax, but he had inspired a number of younger teachers. His successors at Boularderie, Lachlan Macdonald (a native of Cape Breton) and Alexander Munro had both qualified at the Glasgow Normal School. Hugh Munro then set up his own teacher-training seminary in Halifax which followed Stow's techniques (Wood 1991).

When a female school was established as 'an appendage to the Boularderie academy', Mrs Catherine Munro (wife of Alexander), yet another alumni of the Glasgow Normal School was appointed. Alexander Munro provided a basic normal school training for teachers at Boularderie and by 1842 he had managed to provide this for seventeen young teachers, including five Roman Catholics. Stow's methods were perceived to be 'humane' in Nova Scotia in the mid 1800s not least because of the proposed relationship between the teacher and the children and these ideas began to influence common schooling (Wood 2006). When the first Normal School was opened in 1855 in Nova Scotia in Truro, Alexander Forrester, the appointed Principal was influenced by the methods of the Glasgow Normal School and had a strong sense that moral education was the foundation of teacher training (Perry 2003).

Stow and his methods attracted praise from different parts of Europe and from America, though from like-minded individuals. Two prominent examples are the records of the visits of Dr. Alex Dallas Bache, from America and Shartvig Nissan from Norway. Dr Bache visited the Model Infant School of the Glasgow Education Society in 1836. He was impressed by the daily use of the Bible as a means of moral and intellectual training (Bache 1839, p. 160). Nissan visited Scotland in 1852. He was struck by some aspects of Stow's training system and considered it highly suitable for the children of the 'lower group of working people in the large towns' (Stenhouse 1961, p. 147). He was impressed by the focus on moral training, the breadth of the curriculum and the emphasis on the playground and the use of the gallery in the training system.

\section{Concluding remarks}

Stow was not always considered to be a great theorist nor an innovative thinker (Prochner 2009). Stow had not attended university and he faced some opposition from the university educated teachers in parochial schools and clergy who were antipathetic to his aims and methods (Wood 1987). The emerging Educational Institute of Scotland (established 1847) argued for the university education of teachers. There was a further view that the Normal Schools taught a range of subjects that was too wide and at a level that was too low. Some of the nuances of his differentiation between training and teaching are hard to discern to contemporary thinkers and the simultaneous instruction/answers he advocated could easily devolve into rote learning, despite his assurances. The report by J. Gibson HMI in 1841 was critical of the extremely limited level of previous knowledge of the average student who entered the Normal Seminary (he acknowledged some exceptions). HMI Gibson pointed out that while the students were successfully trained to give a gallery lesson, there was too much value accorded to these lessons and insufficient time devoted to other aspects of the organisation and the management of learning and teaching.

In the three phases of his educational work, Stow demonstrated an unrelenting commitment and dedication. While he may not have been an innovative thinker, he had an ability to adopt and synthesise different ideas and he had a vision for a coherent educational system that extended from the infant school to the training of teachers. All of this was strongly 
rooted in Christian beliefs that were Calvinist and evangelical (beliefs that attracted both approbation and disapproval). As far as he was concerned, the scriptures had to have a preeminent position in schooling and in religious and moral education. The teacher was expected to have a thorough knowledge and understanding of the scriptures. His ideas on religious and moral education will appear anachronistic, over concerned with the Bible and indoctrinatory to the modern educator. These were ideas that informed his Christian philanthropy and reflected the concern, shared by other educationalists of the time, to protect the poor children from the darker influences surrounding them in the streets, wynds and closes of the city, the 'evil companionship on the streets' (Third Report of the Glasgow Educational Society's Normal Seminary 1837a). This was a concern that extended to protecting the student teachers from the 'contaminating influences of a large city' (Gibson 1841).

There are, of course, also serious implications in the way he conceived the school day and his understanding of the interaction between the teachers and the children; there was a strong element of social and religious control. His vision of school education was motivated by a desire to educate but also to socialise the poor working class and create good Christians, a vision and motivation that was shared by contemporary innovators in education such as Bell, Lancaster and Wilderspin (Digby and Searby 1981). The close contact between the teacher and the pupil throughout the school day in Stow's vision of school enabled a strict form of social control and a constant monitoring of the behaviour of the children in the gallery, the class and in the playground. This control and monitoring extended to the teacher in the Normal Seminary who was expected to be pious and of good moral character, and whose behaviour was monitored in the seminary and in their residences.

The view in Nova Scotia in the mid 1850s that his approach was 'humane' can be justified in some respects and these can be discerned in the positive aspects of his educational ideas and practice. He did not value competition and prizes and merits. The relationship between the master and pupil, albeit one of control, was intended to be based on 'on mutual respect and affection based on Christian love'. This respect and affection were reflected in the fact that Stow did not believe in physical punishment and that the threat of expulsion was not to be used as a mode of discipline. He promoted education for under-fives, especially in the towns and cities. He advocated the use of Music and Physical Education and he valued the importance of a well-appointed playground and outdoor play for the children.

Open Access This article is licensed under a Creative Commons Attribution 4.0 International License, which permits use, sharing, adaptation, distribution and reproduction in any medium or format, as long as you give appropriate credit to the original author(s) and the source, provide a link to the Creative Commons licence, and indicate if changes were made. The images or other third party material in this article are included in the article's Creative Commons licence, unless indicated otherwise in a credit line to the material. If material is not included in the article's Creative Commons licence and your intended use is not permitted by statutory regulation or exceeds the permitted use, you will need to obtain permission directly from the copyright holder. To view a copy of this licence, visit http://creativecommons.org/licenses/by/4.0/.

\section{References}

Aldrich, R. (2013). The British and Foreign school society, past and present. History of Education Researcher, 91, 5-12.

Bache, A. D. (1839). Report on education in Europe to the trustees of the Girard College for Orphans. Philadelphia: Lydia R. Bailey. 
Betchaku, A. (2007). Thomas Chalmers, David Stow and the St. John's experiment; a study in educational influence in Scotland and beyond, 1819-c.1850. Journal of Scottish Historical Studies, 27(2), $170-190$.

Brown, S. J. (1982). Thomas Chalmers and the godly commonwealth in Scotland. Oxford: Oxford University Press.

Brown, S. J. (2019). After the disruption: The recovery of the National Church of Scotland, 1843-1874. Scottish Church History, 48(2), 103-125.

Campbell, C. (2014). Teaching and Pedagogy (1). DEHANZ Dictionary. https://dehanz.net.au/entries/teach ing-pedagogy-1/. Accessed 24 May 2020.

Chambers, R. (1838). The Gazetteer of Scotland. Glasgow: Blackie and Sons.

Circular of Information of the Bureau of Education for June 1872. (1872). Education in the West Indies. Washington: Government Printing Office.

Cleland, J. (1832). Enumeration of the inhabitants of the City of Glasgow and County of Lanark for the Government Census of 1831. Glasgow: John Smith \& Son.

Connell, W. F. (1950). The educational thought and influence of Matthew Arnold. London: Routledge.

Cruickshank, M. (1966). David Stow, Scottish Pioneer of teacher training in Britain. British Journal of Educational Studies., 14(2), 205-215.

Davis, R., \& O’Hagan, F. (2010). Robert Owen. London: Continuum.

Digby, A., \& Searby, P. (1981). Children, school and society in nineteenth-century England. London: Macmillan.

Donnachie, I. (2014). People, places and spaces: Education in Robert Owen's New Society. In S. Mills \& P. Kraftl (Eds.), Informal Education, childhood and youth (pp. 81-96). Basingstoke: Palgrave Macmillan.

Fraser, W. R. (1868). Memoir of the life of David Stow. London: James Nisbet \& Co.

Fraser, W. H., \& Maver, I. (1996). Tackling the problems. In W. H. Fraser \& I. Maver (Eds.), Glasgow volume II: 1830-1912 (pp. 394-440). Manchester: Manchester University Press.

Free Church of Scotland. (1845). Actings and proceedings of the general assembly of the Free Church of Scotland. Edinburgh: John Greig.

Free Church of Scotland. (1847). Proceedings of the general assembly of Free Church of Scotland. Held at Edinburgh May 1847. Edinburgh: W.P. Kennedy.

Free Church of Scotland. (1848). Proceedings of the general assembly of Free Church of Scotland. Held at Edinburgh May 1848. Edinburgh: W.P. Kennedy.

GB Historical GIS/University of Portsmouth, Glasgow City through timelPopulation Statistics I Total Population. (2020). A vision of Britain through time. Retrieved March 26, 2020, from https://www.visio nofbritain.org.uk/unit/10217751/cube/TOT_POP.

Gibson, J. (1841). Report by John Gibson Esq. on the Glasgow normal seminary. In: Minutes of the Council on Education 1841-1842. London: William Clowes and Sons.

Glasgow Educational Society's Normal Seminary. (1837a). The third report of the Glasgow Educational Society's Normal Seminary, 1836. Glasgow: William Collins \& Co.

Glasgow Educational Society's Normal Seminary. (1837b). The fourth report of the Glasgow Educational Society's Normal Seminary, 1837. Glasgow: William Collins \& Co.

Glasgow Infant Society. (1829). First Annual Report of the Glasgow Infant Society. Glasgow: Glasgow Infant Society.

Goodlad, L. M. E. (2003). Victorian literature and the Victorian State. Character rand Governance in a Liberal Society. Baltimore: The John Hopkins University Press.

Gordon, H. M. I. (1856). Report on the Glasgow established Church Normal College. In Minutes of the Committee of Council on Education, 1856-1857. London: George E. Eyre and William Spottiswoode.

Hamilton, D. (1989). Towards a theory of schooling. Barcombe: The Falmer Press.

Hillis, P. (1996). The Church college period, 1843-1904. In M. M. Harrison \& W. B. Marker (Eds.), Teaching the teachers. The history of Jordanhill College of Education 1828-1993 (pp. 13-30). Edinburgh: John Donald Publishers Ltd.

Jones, L. G. E. (1924). Historical development. In D. Hartley \& M. Whitehead (Eds.), Teacher education. Major themes (Vol. 2, pp. 106-127). London: Routledge.

Kay, J. P. (1838). Report on education, addressed to the poor law commissioners in England. In Home and foreign missionary record for the Church of Scotland, 1838.

Komatsu, K. (2003). Towards a history of classroom operations. Paper presented at the European Conference on Educational Research. University of Hamburg, 17-20 September 2003.

Mallon, R. (2020). A church for Scotland? The Free Church and Scottish nationalism after the disruption. Scottish Church History, 49(1), 1-24.

Markus, T. A. (1993). Buildings and power: Freedom and control in the origin of modern building types. London: Routledge. 
McCann, W. P. (1966). Samuel Wilderspin and the early infant schools. British Journal of Educational Studies, 14(2), 188-204.

McDermid, J. (2012). The schooling of girls in Britain and Ireland, 1800-1900. London: Routledge.

Moody, G. (Ed.). (1844). The English Journal of Education. London: Darton \& Co.

Murphy, J. (1971). Church, state and schools in Britain, 1800-1970. Abingdon: Routledge.

Newman, N. F. (1998). Shapes and spaces: Inside Joseph Lancaster's Monitorial "Laboratory". The Journal of Educational Thought, 32(2), 139-168.

Nicoll, M. M. (1984). Scottish college of education libraries: early history to 1958. Journal of Librarianship and Information Science, 16(1), 34-51.

O’Donoghue, T., \& Moore, K. (2019). Teacher preparation in Australia: History, policy and future directions. Bingley: Emerald Publishing Limited.

Oswell, D. (2013). The agency of children. Cambridge: Cambridge University Press.

Paterson, A., Cormack, P., \& Green, W. (2012). The child, the text and the teacher: reading primers and reading instruction. Pedagogia Historica, 48(2), 185-196.

Perry, G. D. (2003). "The grand regulator": State schooling and the normal-school idea in Nova Scotia, 1838-1855. Acadiensis Journal of the History of the Atlantic Region, 32(2), 60-83.

Prochner, L. (2009). A history of early childhood education in Canada, Australia and New Zealand. Vancouver: The University of British Columbia Press.

Rich, R. W. (1933). The training of teachers in England and Wales during the nineteenth century. Cambridge: Cambridge University Press.

Ritchie, D. (2018). 'Justice must prevail': The Presbyterian review and Scottish Views of Slavery, 18311848. The Journal of Ecclesiastical History, 69(3), 557-584.

Rusk, R. (1933). A history of infant education. London: University of London Press Ltd.

Sedra, P. (2011). Exposure to the eyes of god: monitorial schools and Evangelicals in early nineteenth century England. Paedagogia Historica, 47(3), 263-281.

Sengupta, P. (2011). Pedagogy for religion. Berkeley: University of California Press.

Stanley-Blackwell, L. C. C. (1983). The well-watered garden: The Presbyterian Church in Cape Breton, 1798-1860. Sydney: University College of Cape Breton Press.

Stenhouse, L. (1961). Hartvig Nissen's impressions of the Scottish educational system in the mid-nineteenth century. British Journal of Educational Studies, 9(2), 143-154.

Stevenson, J. (2012). Fulfilling a vision. The contribution of the Church of Scotland to School Education, 1772-1872. Eugene, OR: Pickwick Publications.

Stewart, W. A. C., \& McCann, W. P. (1967). The educational innovators 1750-1880. London: MacMillan.

Stow, D. (1834). Moral training, Infant and Juvenile, as applicable to the condition of the populations of large towns. Appendix in D. Stow (1847) National Education. London: Hatchard and Son.

Stow, D. (1839). National education: Supplement to 'Moral training' and 'The training system', with plans for erecting and fitting up training schools. London: W.R. McPhun.

Stow, D. (1850). The training system, the moral training school, and the normal seminary (8th ed.). Longman, Brown, Green and Longmans: London.

Stow, D. (1854). Moral training school and normal seminary for preparing school-trainers and governesses (10th ed.). London: Longman, Brown, Green and Longmans.

Stow, D. (1856). The training system of education for the moral and intellectual elevation of youth (7th ed.). Glasgow: Blackie and Son.

Stow, D. (1859). Bible training: A manual for Sabbath school teachers and parents (9th ed.). Edinburgh: Thomas Constable and Co.

Theobald, M. J. (1996). Knowing women: Origins of women's education in nineteenth century Australia. Cambridge: Cambridge University Press.

Thompson, A. (2018). MLE as non-place. In L. Benade \& M. Jackson (Eds.), Transforming education. Design and governance in global contexts (pp. 107-120). Singapore: Springer.

Tschurenev, J. (2008). Diffusing useful knowledge: the monitorial system of education in Madras, London and Bengal 1789-1840. Paedagogia Historica, 44(3), 245-264.

Whitbread, N. (1972). The evolution of the Nursery-Infant School. London: Routledge.

White, G. (1996). David Stow. In M. M. Harrison \& W. B. Marker (Eds.), Teaching the teachers. The history of Jordanhill College of Education 1828-1993 (pp. 1-12). Edinburgh: John Donald Publishers Ltd.

White, G. (2010). A sort of Amateur schoolmaster; the life, work and influence. Unpublished PhD thesis, University of the West of Scotland.

Wilson, J. D. (1967). The Junior students system. In T. R. Bone (Ed.), Studies in the history of Scottish education 1872-1939 (pp. 191-242). London: University of London Press. 
Wood, B. A. (1991). The significance of the evangelical Presbyterian politics in the construction of sate schooling: A case study of the Pictou district, 1817-1866. Acadiensis Journal of the History of the Atlantic Region, 20(2), 62-85.

Wood, B. A. (2006). Evangelical balance sheet. Character, family and business in Mid-Victorian Nova Scotia. Waterloo: Wilfrid Laurier University Press.

Wood, H. P. (1987). David Stow and the Glasgow Normal Seminary. Glasgow: Jordanhill College of Education.

Woodham-Smith, P. (2012). History of the Froebel movement in England. In E. Lawrence (Ed.), Friedrich Frobel and English education (pp. 34-94). Abingdon: Routledge.

Publisher's Note Springer Nature remains neutral with regard to jurisdictional claims in published maps and institutional affiliations. 